\title{
MODUL PEMBELAJARAN PJOK TEMATIK TERITEGRATIF SUB TEMA AKU ISTIMEWA UNTUK PESERTA DIDIK KELAS 1 SEKOLAH DASAR
}

\author{
Komang Irfan Tri Eri Eryanto1, Wahjoedi ${ }^{2}$, Ni Putu Dwi Sucita Dartini ${ }^{3}$ \\ 1,2,3 Prodi Pendidikan Jasmani, Kesehatan dan Rekreasi, \\ Universitas Pendidikan Ganesha \\ Singaraja, Indonesia \\ e-mail: koman.irfan19@gmail.com, wahjoedi@undiksha.ac.id, \\ sucita.dartini@undiksha.ac.id
}

\begin{abstract}
Abstrak
Tujuan penelitian ini adalah mengembangkan modul pembelajaran Pendidikan Jasmani, Olahraga dan Kesehatan (PJOK) tematik terintegratif Subtema "Aku Istimewa" untuk peserta didik kelas 1 Sekolah Dasar di Kecamatan Buleleng. Metode penelitian yang digunakan adalah R\&D dengan desain pengembangan menggunakan model Borg \& Gall sampai pada pengembangan produk yang divalidasi oleh ahli. Subjek dalam penelitian ini adalah peserta didik kelas 1 SD di Kecamatan Buleleng. Analisis data menggunakan analisis data deskriptif kuantitatif dengan mencari persentase validasi produk. Hasil penelitian menunjukkan, uji validasi produk oleh ahli isi dengan persentase $90,58 \%$ berada pada kualifikasi sangat baik, sedangkan dari ahli media pembelajaran memperoleh presentase $93,3 \%$ berada pada kualifikasi sangat baik sehingga produk layak untuk diujicobakan. Hasil uji lapangan persiapan yang dilakukan di SDN 5 Jineng Dalem dan SDN 1 Penglatan memperoleh rata-rata persentase 92,12\% dengan kualifikasi sangat baik. Hal ini menunjukkan modul yang dikembangkan layak digunakan dan memerlukan studi lanjut untuk ujicoba lapangan dan uji efektifitas.
\end{abstract}

Kata kunci: PJOK, pembelajaran tematik, modul pembelajaran

\begin{abstract}
The purpose of this research was to develop an integrated thematic physical education learning module for the sub-theme of "I Am Special" for grade 1 elementary school students in Buleleng District. The research method used was $R \& D$ with a development design using the Borg \& Gall model until develop preliminary form of product.. Data analysis used descriptive quantitative for the percentage of product validation. The results showed, the product validation test by content experts with a percentage of $90.58 \%$ was in very good qualifications. From learning media experts with a percentage of $93.3 \%$ was in very good qualifications so that the product was feasible to be tested. The conclusion in this study is that the module developed is suitable for use and requires further field test and effectiveness testing.
\end{abstract}

Keywords: physical education, thematic learning, learning model

\section{PENDAHULUAN}

Peraturan Pemerintah No. 32 Tahun 2013 tentang Perubahan atas Peraturan Pemerintah No. 19 Tahun 2005 tentang Standar Nasional Pendidikan salah satunya adalah perubahan model pendekatan pembelajaran di Sekolah Dasar (SD) yaitu dengan pendekatan tematik terpadu. Dimyati \& Mudjiono (2009:157) mendefinisikan pembelajaran sebagai proses yang diselenggarakan oleh guru untuk membelajarkan siswa dalam belajar memperoleh dan memperoses pengetahuan, keterampilan dan sikap. Sedangkan pembelajaran tematik dimaknai sebagai pembelajaran yang dirancang berdasarkan tema-tema tertentu (Trianto, 2010). Pembelajaran tematik lebih menekankan pada penerapan konsep belajar sambil melakukan sesuatu. Lubis (2018) 
mengatakan bahwa pembelajaran tematik adalah penggabungan beberapa materi menjadi satu kepaduan dalam lingkup SD atau MI. Anak usia SD memiliki kecenderungan untuk belajar: (1) kongkrit yaitu belajar melalui hal yang dapat dilihat, didengar, dan diraba; (2) integratif yaitu memandang sesuatu yang dipelajari sebagai suatu keutuhan dan belum mampu memilah-milah konsep dari berbagai disiplin ilmu; dan (3) hirarki yaitu belajar mulai dari hal yang sederhana ke hal- hal yang lebih kompleks (Lubis, 2018). Dengan kecenderungan belajar demikian, maka peserta didi SD akan lebih mudah belajar dengan pendekatan pembelajaran terpadu yang menekankan pada pengalaman dan kebermaknaan pada anak. Pada kelas 1 SD tema yang dikembangkan dikaitkan dengan beberapa mata pelajaran yaitu Bahasa Indonesia, Matematika, PPKn, Seni Budaya dan Prakarya (SBdP), serta Pendidikan Jasmani, Olahraga dan Kesehatan (PJOK). PJOK merupakan pendidikan melalui aktivitas jasmani yang dijadikan sebagai media untuk mencapai perkembangan individu secara menyeluruh. Hal ini sesuai dengan definisi yang dikemukakan oleh Husdarta (2009) bahwa pendidikan jasmani adalah proses pendidikan yang memanfaatkan aktivitas fisik untuk menghasilkan perubahan holistik dalam kualitas individu, baik dalam hal fisik, mental, serta emosional.

Salah satu permasalahan atau tantangan yang dihadapi guru PJOK dalam pengimplemetasian pembelajaran tematik di sekolah karena terbatasnya sumber pembelajaran. Adanya buku pegangan guru dan siswa dirasakan belum cukup karena contoh kegiatan sedikit sehingga guru diharapkan dapat mengembangkan kegiatan lainnya diluar contoh yang diberikan. Berdasarkan hasil analisis kebutuhan tentang dengan menyebarkan kuesioner kepada 10 orang guru PJOK di Kecamatan Buleleng, diketahui bahwa 9 guru (90\%) menyatakan mengalami kesulitan dalam menerapkan pembelajaran PJOK berbasis tematik dengan alasan: (1) karena proses pembelajaran dengan metode daring. (2) pada saat praktek di lapangan harus sesuai dengan materi dan gerak yang dilakukan peserta didik terbatas. (3) kurangnya sarana dan prasarana olahraga yang memadai (4) materi yang ada didalam buku tematik masih secara umum dan perlu materi lebih agar peserta didik lebih mengerti. (5) terbatasnya contoh pada kegiatan PJOK dalam buku guru maupun buku peserta didik. (6) kurangnya pelatihan atau sosialisasi tentang pembelajaran PJOK berbasis tematik. Hasil observasi juga menunjukkan bahwa 9 dari 10 guru (90\%) mengharapkan adanya modul pembelajaran PJOK berbasis tematik yang dapat mengeksplorasi gerak peserta didik sebagai panduan dalam pembelajaran.

Berdasarkan analisis kebutuhan dan mendesaknya kebutuhan guru PJOK sekolah dasar di Kecamatan Buleleng untuk itu dipandang perlu dikembangkan modul pembelajaran tematik terintegratif pada mata pelajaran PJOK.Pengembangan tentang modul pembejaran tematik pernah dilakukan oleh beberapa peneliti seperti Jiwa et al., (2013) menemukan bahwa ada perbedaan prestasi belajar antara siswa yang mengikuti pembelajaran tematik dengan yang mengikuti pembelajaran konvensional. Dimana siswa yang mengikuti pembelajaran tematik memilki prestasi belajar yang lebih baik. Senada dengan itu Octaviani (2017) mengembangkan bahan ajar tematik dalam bentuk activity book dalam implementasi kurikulum 2013 kelas 1 sekolah dasar menunjukkan bahwa bahwa terjadi perubahan prestasi belajar peserta didik ke arah yang lebih baik setelah menggunakan activity book. Pada penelitian ini, dikembangkan modul permainan tematik terintegratif dalam pembelajaran PJOK pada tema "diriku" subtema "aku istimewa" untuk peserta didik kelas 1 Sekolah Dasar di Kecamatan Buleleng. 


\section{Volume 8, Nomor 1, April 2021 \\ ISSN 2356-3397 (Print) | ISSN 2597-4505 (Online)}

\section{METODE}

Metode yang digunakan dalam penelitian ini adalah metode Research and Development (R\&D). R\&D adalah metode penelitian yang diarahkan untuk merumuskan, memperbaiki, mengembangkan, menghasilkan dan meguji keefektifan produk, model/metode/strategi, prosedur tertentu yang lebih baru, efektif, efisien dan bermakna (Putra, 2012). Pengembangan produk mengunakan desain dari Borg \& Gall (1996) yang terdiri dari 10 tahap namun karena keterbatasan waktu maka pada penelitian ini hanya sampai pada tahapan ketiga yang meliputi: (1) studi pendahuluan dan pengumpulan informasi (kajian pustaka, pengamatan kelas, identifikasi permasalahan yang dijumpai dalam pembelajaran), (2) perencanaan, dan 3) pengembangan bentuk produk awal yang telah divalidasi oleh ahli

Setelah prototipe produk dikembangkan maka dilakukan uji validasi produk oleh 2 orang ahli di bidangnya masing-masing yaitu ahli isi atau materi dan ahli media pembelajaran. Para ahli memberikan penilaian dan saran perbaikan dari produk yang dikembangkan. Pengumpulan data dilakukan dengan observasi, wawancara, angket dan dokumentasi. Teknik analisis data menggunakan analisis deskriptif berupa persentase. Sedangkan saran dan masukan untuk perbaikan model dianalisis dengan analisis kualitatif. Pengolahan data kuantitatif menggunakan rumus:

Persentase $=\frac{\text { skor yang diperoleh }}{\text { skor maksimal }} \times 100$

Untuk selanjutnya hasil perhitungan dibandingkan dengan norma untuk memutuskan validasi produk seperti tabel 1 berikut,

Tabel 1. Persentase Hasil Analisis Data

\begin{tabular}{ccc}
\hline Tingkat Pencapaian (\%) & Kualifikasi & Keterangan \\
\hline $90-100$ & Sangat baik & Tidak perlu direvisi \\
$75-89$ & Baik & Sedikit direvisi \\
$65-79$ & Cukup & Direvisi secukupnya \\
$55-64$ & Kurang & Banyak hal yang direvisi \\
$1-54$ & Sangat kurang & Diulangi membuat produk \\
\hline
\end{tabular}

\section{HASIL DAN PEMBAHASAN \\ Hasil}

Hasil dari penelitian ini adalah prototipe "Modul Permainan Tematik PJOK untuk Kelas 1 Sekolah Dasar Tema: “"Diriku” sub tema "Aku Istimewa”" yang telah divalidasi oleh ahli. Tahapan penelitian adalah sebagai berikut.

\section{Studi Pendahuluan dan Pengumpulan Informasi}

Studi pendahuluan dilakukan guna mengumpulkan informasi identifikasi permasalahan yang dijumpai dalam pembelajaran PJOK di kelas 1. Studi pendahuluan dilakukan dengan wawancara dan penyebaran kuesioner kepada guru PJOK SD di Kecamatan Buleleng. Dari hasil wawancara dan penyebaran kuesioner kepada 10 orang guru diperoleh informasi bahwa sebanyak 9 orang (90\%) masih mengalami kendala dalam melaksanakan pembelajaran PJOK berbasis tematik pada kelas rendah. Sebanyak 9 orang guru (90\%) mengharapkan adanya modul model pembelajaran PJOK berbasis tematik sebagai pedoman dan contoh dalam mengembangkan pembelajaran PJOK di sekolah. 


\section{Volume 8, Nomor 1, April 2021 \\ ISSN 2356-3397 (Print) | ISSN 2597-4505 (Online)}

\section{Perencanaan}

Kegiatan perencanaan produk dimulai dari (1) melakukan analisis kurikulum khusunya Kompetensi Inti (KI) dan Kompetensi Dasar (KD) di kelas 1 SD, (2) menentukan tema yang akan dikembangkan dari berbagi tema yang ada di kelas 1, (3) melakukan analisa terhadap tema yang dipilih, (4) merencanakan kegiatan yang akan dipilih sebagai bahan pembuatan modul, dan (5) membuat kuesioner untuk uji ahli (expert judgement). Berdasarkan pemetaan tersebut dan wawancara serta diskusi dengan guru PJOK ditentukan bentuk kegiatan adalah permainan tematik berbasis aktivitas jasmani atau gerak. Kegiatan permainan dipilih dengan mempertimbangkan karakteristik anak usia 7-8 tahun yang menyukai permainan/ bermain. Melalui bermain anak dapat belajar menerima, berekspresi dan mengatasi masalah dengan cara yang positif.

\section{Pengembangan Produk Awal}

Sesuai dengan perencanaan yang telah dilakukan maka dibuatkan 4 buah permainan yang menyesuaikan dengan KI dan KD PJOK pada tiap kegiatan pembelajaran serta mengintegrasikan dengan mata pelajaran lainnya. Format untuk setiap permainan terdiri dari nama permainan, pengertian permainan, tujuan permainan, alat yang dibutuhkan, lapangan permainan serta cara bermain. Dari hasil pengembangan produk dihasilkan 4 buah permainan dimana masing-masing kegiatan pembelajaran terdapat 2 buah permainan.

Setelah produk dikembangkan maka dilakukan uji validasi produk oleh ahli meliputi ahli isi/materi dan ahli media. Ahli isi adalah dosen yang memiliki kompetensi di bidang pembelajaran PJOK sedangkan ahli media adalah dosen yang memiliki kompetensi di bidang teknologi pembelajaran. Hasil uji validasi oleh ahli dapat dilihat pada tabel 2.

Table 2. Hasil Validasi Produk oleh Ahli

\begin{tabular}{llcccc}
\hline No & Ahli & Skor & $\begin{array}{c}\text { Skor } \\
\text { Maksimal }\end{array}$ & Persentase & Kategori \\
\hline 1 & Isi / Materi & 77 & 85 & $90,58 \%$ & Sangat Baik \\
2 & Desain & 56 & 60 & $93 \%$ & Sangat Baik \\
& Rata-rata Persentase & & $91,79 \%$ & Sangat Baik \\
\hline
\end{tabular}

Hasil uji validasi dari ahli materi dan desain diperoleh persentase 90,58\% dan 93\% dalam kategori sangat baik. Rata-rata persentase dari kedua orang ahli adalah $91,79 \%$ dalam kategori sangat baik. Sehingga dapat disimpulkan produk layak digunakan untuk ujicoba lapangan tahap awal. Sebelum diujicobakan dilakukan beberapa revisi sesuai dengan saran dan masukkan dari validitator untuk perbaikan draf produk awal yang dibuat.

\section{Pembahasan}

Pengembangan Modul Pembelajaran PJOK Tematik Terintegratif Tema "Diriku" (Sub Tema: "Aku Istimewa") untuk Peserta Didik Kelas 1 SD di-Kecamatan Buleleng berawal dari permasalahan yang ditemukan dalam keadaan dilapangan secara langsung melalui observasi dan melakukan analis kebutuhan di sekolah. Berdasarkan hasil observasi di beberapa sekolah yaitu: SDN 1 Jineng Dalem, SDN 2 Jineng Dalem, SDN 3 Jineng Dalem, SDN 5 Jineng Dalem, SDN 4 Banyuning, SDN 1 Banyuning, SDN 2 Penglatan, SDN 2 Penarukan, SDN 3 Penglatan, SDN 1 Penglatan, di temukan masalah yang sama. Berdasarkan hasil analisis kebutuhan tentang modul pembelajaran PJOK dengan menyebarkan kuesioner kepada 10 orang guru PJOK di Kecamatan Buleleng, menunjukkan bahwa 9 guru (90\%) menyatakan mengalami kesulitan dalam menerapkan pembelajaran PJOK berbasis tematik. Untuk itu dipandang perlu utuk 
melakukan penelitian tentang pengembangan modul pembelajaran PJOK berbasis tematik terpadu di sekolah dasar agar tujuan dari pembelajaran dapat tercapai. Modul terdiri dari cover, pendahuluan, cara menggunakan, daftar isi, subtema, pemetaan kompetensi dasar tiap subtema dan permainan. Terdapat 4 buah permainan yang dikembangkan dalam modul ini yaitu permainan (1) puzzle kata, (2) puzzle huruf, (3) Permainan sirkuit kata, (4) right place. Berdasarkan hasil uji validasi oleh ahli diperoleh hasil yaitu (1) ahli isi/materi skor yang diperoleh 77 atau dengan prosentase $90,58 \%$ dalam kategori sangat baik, (2) ahli media dengan skor 56 dengan prosentase $93 \%$ atau dalam kategori sangat baik. Kedua ahli memberikan skor sangat baik kepada produk yang dikembangkan dengan rata-rata persentase $91,79 \%$, sehingga dapat disimpulkan bahwa modul permainan tematik untuk kelas I SD tema "Diriku" sub tema "Aku Istimewa" layak untuk diujicobakan di lapangan.

Modul yang dikembangakan berisikan permainan dengan aktivitas gerak. Pemilihan permainan tematik sesuai dengan kurikulum 2013 yang berlaku di kelas I SD dimana pada kelas rendah (I, II, dan III) pembelajaran PJOK terintegrasi dengan tematema tertentu. Pembelajaran tematik di sekolah dasar akan membantu peserta didik karena sesuai dengan karakteristik perkembangan peserta didik yang melihat segala sesuatu sebagai suatu keutuhan. Pembelajaran tematik menekankan pada penerapan konsep sambil melakukan (learning by doing) hal ini dimaksudkan agar peserta didik dalam proses pembelajaran dapat memberikan makna yang utuh pada berbagai tema yang disediakan (Rusman, 2011). Pengembangan tentang model pembejaran tematik pernah dilakukan oleh beberapa peneliti seperti (Giartama et al., 2018) yang mengambangkan model pembelajaran tematik integratif penjasorkes pada mata pelajaran ilmu pengetahuan alam di sekolah dasar yang menunjukkan kelayakan model yang dibuat yang mampu membuat nilai rata-rata tes pengetahuan peserta didik $97 \%$ dalam kategori sangat baik. Penelitian lain dilakukan oleh Widyaningrum (2012) menunjukkan bahwa peserta didik taman kanak-kanak yang diajar secara tematik memiliki kemampuan dan kesiapan yang lebih baik dalam mengikuti pembelajaran dibandingkan mereka yang tidak diajar secara tematik.

Permainan dipilih sebagai bentuk kegiatan PJOK adalah permainan berbasis gerak, sebab pembelajaran PJOK adalah pembelajaran melalui gerak sebagai medianya. Bermain merupakan kegiatan yang sangat digemari oleh anak-anak dan orang dewasa. Dengan bermain dapat dikembangkan kestabilan dan pengendalian emosi yang sangat penting bagi keseimbangan mental (Nurhasan, 2005). Bermain memberi kontribusi alamiah untuk belajar dan berkembang, dan tidak ada satu program pun yang dapat menggantikan pengamatan, aktivitas, dan pengetahuan langsung anak pada saat bermain. Melalui permainan dapat meningkatkan keterampilan berpikir anak seperti hasil penelitian Kawuryan, Hastuti, \& Supartinah (2018) menemukan bahwa model pembelajaran tematik berbasis permainan tradisional dan berorientasi pendekatan saintifik terbukti memberikan kontribusi yang signifikan terhadap peningkatan kemampuan berpikir kreatif siswa. Dari berbagai hasil penelitian seperti yang dikutip dari parenteingforbrain.com (2020) bahwa ada beberapa manfaat dari kegiatan bermain yaitu (1) menstimulasi perkembangan otak (2) meningkatkan kecerdasan, (3) meningkatkan kemampuan berpikir kreatif, (4) meningkatkan komunikasi, kosakata dan bahasa, (5) meningkatkan kemampuan mengelola emosi, (6) mengembangkan kemampuan sosial dan empati, (7) menumbukan dan mengembangkan kemampuan fisik dan mental, (8) mengajarkan pelajaran hidup, dan (9) memperkuat hubungan dengan sesama. Beberapa penelitian yang berkaitan dengan aktivitas bermain pernah diteliti oleh Hidayatullah \& Kristiyanto (2014) tentang model aktivitas belajar gerak berbasis permainan sebagai materi ajar Penjas di kelas I SD. Hasil penelitian menunjukkan tingkat ketuntasan belajar siswa sebesar 97\% setelah diterapkan model aktivitas gerak berbasis permainan. Penelitian tentang permainan 
ISSN 2356-3397 (Print) | ISSN 2597-4505 (Online)

juga menemukan bahwa permainan tradisional dapat meningkatkan kemampuan gerak dasar siswa sekolah dasar kelas rendah (Kusumawati, 2017).

\section{SIMPULAN DAN SARAN \\ Simpulan}

Berdasarkan hasil penelitian dan pembahasan dari penelitian ini, dapat disimpulkan bahwa pengembangan permainan tematik PJOK Tema "Diriku" sub tema "Aku Istimewa" valid menurut ahli dengan hasil menurut para ahli isi sebesar $90,58 \%$ berada pada kualifikasi sangat baik dan ahli media sebesar 93,3\% berada pada kualifikasi sangat baik. Untuk itu model ini dapat digunakan pada pembelajaran PJOK kelas 1 SD dengan terlebih dahulu melakukan ujicoba kelayakan

\section{Saran}

Modul dalam penelitian ini masih berupa prototipe yang masih perlu diujicobakan untuk mengetahui kelayakan dan efektifitas produk. Untuk itu diharapkan penelitian lebih lanjut mengenai produk ini khususnya pada uji kelayakan dan efektifitas produk.

\section{DAFTAR PUSTAKA}

Dimyati, \& Mudjiono. (2009). Belajar dan Pembelajaran. PT Rineka Cipta.

Gall, M. D., Borg, W. R., \& Gall, J. P. (1996). Educational Research: An introduction. Longman Publishing.

Giartama, G., Hartati, H., Destriani, D., \& Victoriand, A. R. (2018). Pengembangan Model Pembelajaran Tematik Integratif Penjasorkes pada Mata Pelajaran IImu Pengetahuan Alam di Sekolah Dasar. Sebatik, 22(2), 167-171.

Hidayatullah, M. F., \& Kristiyanto, A. (2014). Model Aktivitas Belajar Gerak Berbasis Permainan Sebagai Materi Ajar Pendidikan Jasmani (Penelitian Pengembangan pada Siswa Kelas I Sekolah Dasar). Indonesian Journal of Sports Science, 1(1), 218350.

Husdarta, H. J. . (2009). Manajemen Pendidikan Jasmani. Alfabeta.

Jiwa, I. W., Dantes, N., \& Marhaeni, A. (2013). Pengaruh implementasi pembelajaran tematik terhadap prestasi belajar ditinjau dari motivasi Belajar pada siswa kelas iv gugus empat Di kecamatan gianyar. Jurnal Penelitian Dan Evaluasi Pendidikan Indonesia, 3(1).

Kawuryan, S. P., Hastuti, W. S., \& Supartinah, S. (2018). The Influence of Traditional Games-Based and Scientific Approach-Oriented Thematic Learning Model Toward Creative Thinking Ability. Cakrawala Pendidikan, 1, 237921.

Kusumawati, O. (2017). Pengaruh Permainan Tradisional Terhadap Peningkatan Kemampuan Gerak Dasar Siswa Sekolah Dasar Kelas Bawah. TERAMPIL: Jurnal Pendidikan Dan Pembelajaran Dasar, 4(2), 124-142. https://doi.org/https://doi.org/10.24042/terampil.v4i2.2221

Lubis, M. A. (2018). Pembelajaran Tematik di SD/MI: Pengembangan Kurikulum 2013. Samudra Biru.

Nurhasan. (2005). Petunjuk Praktis Pendidikan Jasmani (Bersatu Membangun Manusia yang Sehat Jasmani dan Rohani). Unesa University Press.

Octaviani, S. (2017). Pengembangan Bahan Ajar Tematik Dalam Implementasi Kurikulum 2013 Kelas 1 Sekolah Dasar. EduHumaniora / Jurnal Pendidikan Dasar Kampus Cibiru, 9(2), 93. https://doi.org/10.17509/eh.v9i2.7039 


\section{ISSN 2356-3397 (Print) | ISSN 2597-4505 (Online)}

Putra, N. (2012). Research \& Development Penelitian dan Pengembangan: Suatu pengantar. In Jakarta: Rajawali Pers. Rajawali Pers.

Rusman. (2011). Model-Model Pembelajaran: Mengembangkan Profesionalisme Guru. Rajawali Pers/PT Raja Grafindo Persada.

Trianto. (2010). Mengembangkan Model Pembelajaran Tematik. Prestasi Pustaka.

Widyaningrum, R. (2012). Model Pembelajaran Tematik di MI/SD. Cendekia: Jurnal Kependidikan Dan Kemasyarakatan, 10(1), 107-120. 